\title{
The Third Millennium Secretary And Information \& Communication Technology: Nigerian Experience
}

Adewale Onifade, Ph D, Moshood Abiola Polytechnic, Nigeria

\begin{abstract}
The academic qualifications, routine duties, role responsibilities, office equipment and personal attributes of traditional secretary form the basics for the study of the third millennium secretary. Although some of the personal and business attributes of the traditional secretary may appear old, some of them are still relevant in the workplace today. For example, both traditional secretary and the third millennium secretary still carry out routine duties of typing, handling telephone calls, etc., but the third millennium secretary carries out management activities which were hitherto reserved for only the executive. The third millennium secretary is better trained, uses modern technology, manages both human and non-human resources more efficiently, and is better at public relations and communication skills.
\end{abstract}

Keywords: Communication, Efficiency versus Effectiveness, Information, Information Technology, Information and Communication Technology, Public Relations, Secretary, Third Millennium.

\section{INTRODUCTION}

igeria, as an emerging economy, needs modern secretaries if it is to achieve its economic goal. The
importance of an office in the development of an economy cannot be overstressed. It is the secretary
that manages the basic office resources. He manages both tangible and intangible, human and nonhuman resources, such as personnel, machines, materials, money, time, information and methods.

The office is undergoing an impressive revolution which affects the status of the secretarial profession. There is no profession that is as dynamic as the secretarial profession. This is a truism. It is therefore only the secretary that can withstand the changes and challenges of the modern office and survive them. These changes and challenges can be seen in innovation and invention pertaining to equipment, furniture, form designs, nomenclature, environment, technology, attitudes, dressing, responsibilities, training, skill, ability, knowledge, educational institutions and their curricula.

We now have graduates of polytechnics and universities as secretaries, thus posing new challenges to the old secretaries and creating a sense of job insecurity for them. In Nigeria, secretaries used to train in roadside secretarial institutes, Federal Government Training Centres and Staff Development Centres by state governments, all of which are becoming moribund gradually. The inadequate qualification and training in office management and administration and in modern office technology, for the old secretaries, affect their perception of office situations and the world of work, in general.

This article will focus on the definition of relevant terms, history of the secretarial profession (ethics, code of conduct, personal qualities and business attributes), the traditional secretary and his environment, modern office equipment and their functions, advantages and disadvantages of modern office equipment, and the third millennium secretary and his environment. 


\section{DEFINITION/EXPLANATION OF WORDS}

\section{Communication}

Communication has been defined by many people using different words. A complete definition of communication must ensure the following ingredients: speaker (sender or encoder), speech (message), medium (carrier of message e.g.. written or oral) and receiver (decoder). Communication is not complete until a response is received (Wolf \& Kuiper, 1984). Communication, according to Little (1974), is the "process by which information is passed between individuals or organizations by means of previously agreed symbols."

\section{Efficiency versus Effectiveness}

Effectiveness is accomplished by achieving a stated objective. Swinging a sledgehammer against the walls may be an effective way of killing a bothersome fly. In addition, one demonstrates efficiency if that objective is achieved without wasting scarce resources, such as time, talent, or money. Efficiency, therefore, has to do with the relationship between inputs and outputs.

Although a sledgehammer is an effective way of killing flies, it is not very efficient when one takes into consideration the wasted efforts and smashed walls. A fly swatter is both effective and efficient.

Kreitner, Robert. (1980)

\section{Information}

Information, like many other words, has many and varied meanings. Webster New World dictionary (1980) defined information as "knowledge acquired in any manner, facts, data, learning, lore."

Nwankwo (1985) said that information can “...mean interrelated or structured data, including collection, storage, processing and dissemination of news, data ...facts, messages, opinion and comments required in order to react knowledgeably, as well as to be in a position to make appropriate decisions.

Sander (1983) pointed out that information has attributes of a physical resource, such resources as manpower, money and materials. He highlighted the following characteristics of information:

1. Information has value, like money, raw materials or manpower.

2. Information is measurable in terms of use, life and effects on other resources.

3. Information can be valued in terms of collecting, storing and retrieving.

4. Information can be budgeted and controlled.

5. Information can be related in terms of cost and use value to manage objectives.

\section{Information Technology (IT)}

Information Technology (IT), as defined in the Oxford Dictionary of Business (2002), is "The use of computers and other electronic means to process and distribute information." It went further to say that "Information can be transferred between computers using cables, satellite links or telephone lines."

\section{Information and Communication Technology (ICT)}

Having defined information, communication and technology, ICT should be easily defined and understood. Wikipedia states that ICT is an umbrella term that includes all technologies for the communication of information. ICT refers to the technology which helps to generate, process, edit, store, disseminate or communicate information. 


\section{Public Relations (PR)}

Public Relations in wikipedia is defined as a "set of management, supervisory and technical functions that foster an organization's ability to strategically listen to, appreciate and respond to those persons whose mutually beneficially relationships with the organization are necessary if it is to achieve its missions and values" (Robert L. Heath, Encyclopedia of Public Relations).

\section{Secretary}

Hanna et al. in Onifade (2004) defined a secretary as "An assistant to an executive, possessing mastery of office skills and ability, who assumes responsibility without direct supervision, displays initiative, exercises judgment, and makes decisions within the scope of her authority."

\section{Third Millennium}

The third millennium is the period in years from 2000 to 2999. The first millennium consisted of years 1999 and the second millennium were years 1000-1999.

\section{HISTORY OF SECRETARIAL PROFESSION}

Literature on the history of the secretarial profession shows that nobody knows when secretaries originated, but that the Romans were first to employ men as scribes who took down dictation. Men dominated secretarial jobs until the late 1880s. However, in the 1930s, women started to dominate the profession.

In Nigeria, there were few secretaries in the early 1900's because there were no government established training institutions. Organizations employed typists and stenographers as secretaries. These "secretaries" trained in road-side secretarial institutes. These institutes did not have qualified instructors and adequate machines. Therefore, those who employed them were skeptical about their administrative competence, thus limiting their activities to routine or chore office jobs.

In the late 1900's, the state and federal governments started recognizing the need to employ efficient secretaries and established Federal Training Centres in Lagos and Kaduna. The state governments later established Staff Development Centres. Admission requirements into these centres were low. Later, polytechnics were established by both state and federal governments in order to have better trained secretaries. At present, we have a few universities with a Secretarial Administration department where secretaries are trained. The polytechnics are still regarded as the best place to train secretaries. Secretaries command high respect and they easily get jobs. They are versatile because all organizations need them.

In the early days of producing secretaries in Nigeria, people regarded those who went to commercial secondary modern or commercial secondary schools as dullards. The public regarded those who went to secondary grammar schools as highly intelligent - those who would become doctors, lawyers, engineers, etc. Things have interestingly reversed as commercial or business courses are becoming more versatile than the science courses. We now find doctors and other professionals who write accounting examinations.

\section{PROFESSIONALISM IN THE SECRETARIAL PROFESSION}

The American Dictionary (1980) defined professionalism as the "professional status, methods, character or standards." A profession is also defined as an "occupation or vocation requiring training in the liberal arts or the sciences and the advanced study in a specialized field or the body of qualified persons of one specific occupation or field." A professional is "one engaged in a specific activity as a source of livelihood."

Onifade (2003) showed that a profession was defined by Mgbo (1992) and Azuka (1992) as an "occupation that requires advanced training and demands, of its members, a prolonged specialized training in its special field, thereby making them an esoteric group." 
Characteristics, important features or core elements of a profession as presented in Onifade (2003) and Kpeke (1992) and Nwaokolo (1992), are: knowledge, control of entry, organization into professional groups, a code of ethics, conditions of service, freedom to practice the profession and recognition by the public.

Onifade (2003) gave the six characteristics of a profession, as presented by Liberman (1956) and Azuka (1992) as follows: performs an essential social function, founded on a systematic body of knowledge; requires a lengthy period of practical and academic training; has a degree of autonomy; has a code of ethics; and provides inservice and professional growth of members. Still in Onifade (2003), Jackson (1970) stated the following characteristics of a profession must be properly trained in a discipline; the profession should be concerned with wide dissemination of the discipline; should show concern about the proper place of research; the profession should define its standard for practice procedures and should develop a code of practice and ethics; the group interest must be harmonized; and it must have a monopoly over certain knowledge and resources.

Having presented varied shades of opinion on what a profession is, the secretarial profession has a code of ethics, personal qualities and business attributes for its members.

"The ethics of a secretary and office professional are moral principles relating to the job that you will be bound by." These ethics include confidentiality, honesty, loyalty, reliability, responsibility, working unsupervised (meeting deadlines, setting priorities), cooperativeness, flexibility, multi-skilling (learning as much as possible about computer programmes and other positions in the firm), and bribery (do not be tempted to accept gifts or favors from internal or external clients just in case there is an underlying reason). http://www.secretarialsite.com/secretarial _ethics.htm

Lauria (1972) highlighted the following personal attributes of a secretary: adaptable, level-headed, good observer, intuitive, flexible, tactful, friendly, accurate, thorough, fore-thoughtful, takes initiative, self-confident, good listener, good telephone personality, and good appearance.

Harrison (1979) gave the following business attributes of a secretary: has good secretarial and organizing skills, is efficient, reliable, responsible, discreet, tactful, diplomatic, punctual, and takes initiative.

The third millennium secretary is a professional. As such, he should be properly trained and should imbibe the principles of professionalism, and personal and business attributes of a secretary.

\section{TRADITIONAL SECRETARY AND HIS ENVIRONMENT}

There is no gain in saying that the traditional secretary and his environment are different from the millennium secretary and his environment. However, the secretary has always been an indispensable human resource for the chief executive. The secretary is a subordinate who assists his boss.

The traditional secretary is one who existed in the first and second millennium.

\section{CHARACTERISTICS OF THE TRADITIONAL SECRETARY}

\section{Academic Qualification}

He attended roadside institutes and his basic entry qualifications are primary school certificate, secondary modern school certificate, and secondary/grammar school fourth year certificate (G4). At the end of his training, he wrote the Pitman or Royal Society of Arts (RSA) examination in shorthand, and knew how to type and knew all the secretarial duties, the English language, bookkeeping, office practices, etc. The examinations are given in three stages: stage I (ordinary level), stage II (intermediate level), and stage III (advanced level). 
Skills

He should possess high-level shorthand and typewriting skills. To be efficient in the office, he was expected to write between 100-120 words per minute in shorthand and type between 50-60 words per minute. He had to be knowledgeable in the basics and rudiments of bookkeeping and accounting and able to operate the commonly used office machines, such as addressing, duplicating, dictating, billing adding, and calculating machines. He had to be adept in filing systems and have very good human and public relations skills.

\section{The Environment}

Some of the machines that traditional secretaries used were typewriters (manual, electric, Selectric, electronic), franking machines, dictaphone, dictating and stenographic machines, multigraph, power statistical accounting machine, bookkeeping and billing machines, etc. The office of the traditional secretary was closed, decentralized and partitioned. To aid in filing and indexing, wooden and steel cabinets were used for keeping visible card records, visible loose-leaf records, rotary indexing equipment, strip indexing equipment, edge-punched cards, and line reference equipment.

Stencils and master sheets were prepared for ink-and-spirit duplicators and a scanning machine was also used for duplicating purposes. A dedicated word processor, letter opening machine, and folding and inserting machine were frequently used in the office. The office hazards or pitfalls were not pronounced, but the common ones were from a scissors, knife and razor because many things were placed on the wooden shelf and would sometimes fall and wound the secretary. Troublesome and unwanted visitors sometimes made the job unpleasant. Secretaries were expected to prepare tea for the boss, and in the process, hot water might have poured on them. Some executives made flirting overtures to their unwilling secretaries.

The type of nomenclature in vogue in those days included typist, stenographer and secretary, all with distinct descriptions. The typist was purely one who only typed what was given to him. The stenographer, apart from typing, had to take notes in shorthand. The secretary, on the other hand, had to do the work of the typist and stenographer, in addition to administrative work, such as preparing the boss's itinerary, imprest for the office, and some supervision of junior workers. He also received and made telephone calls and greeted visitors accordingly. They were generalist secretaries, not specialist secretaries, and their jobs were routine in nature.

The qualities and responsibilities of the traditional secretary are described in the acronym "SECRETARY" by Ogbenchie: "S" for Secretive, "E" for Educated, "C" for Courteous, "R" for Reliable, "E" for Efficient, "T" for Tactful, "A" for Accommodating, "R" for Responsible, and "Y" for Yielding. He used plenty of paper for correspondence, duplication and forms.

\section{MODERN OFFICE EQUIPMENT, FACILITIES AND THEIR FUNCTIONS}

\section{The computer}

Everybody knows what a computer is. I simply define it as an accurate electronic device that performs calculations and processes information at great speed. Computers come in different sizes, shapes, capacities, etc. We have desktops, laptops, and palmtops. The computer is used in medicine, engineering, architecture, education, banking, etc.

\section{Telephones - mobile and land}

The land line is the most basic office communications tool used by secretaries. The most popular mobile phone used in Nigeria is the GSM Global Systems for Mobile Communication.

\section{Fax Machine}

Just like the telephones, the fax machine transmits information, but in text or document format. 


\section{Internet (www, e-mail, search engine, etc.)}

This is an intangible facility on the computer. WWW stands for worldwide web and it is a collection of information in multimedia form on the internet. This information is stored at locations, called websites, in the form of web pages. Websites are an effective way of distributing information, such as advertisements, technical information, comments, ideas, etc. Other applications on the internet are chatting for simultaneous communication between people and the use of a web camera for seeing while chatting.

Search engines like Google, yahoo, msn, etc. are used to find information on the internet - looking through millions of sources all over the world. For example, when you want to read Nigerian newspapers while living in the U.S., you would be helped through the use of Google.

\section{Teleconferencing}

This facility, usually embedded in the telephone technology, allows more than two people to communicate via phone at the same time. This makes it possible for people in different cities to hold meetings together.

\section{Video Conferencing}

This facility usually makes use of the internet with or without the telephone and allows visual and speech communication among several people at the same time. Like teleconferencing, it enhances remote communication. For example, your colleague in America can remotely participate in a meeting held in Nigeria whereby he sees and hears everybody who attends the meeting in Nigeria as he makes his own contributions.

\section{Scanner}

This machine is used to convert hard copy documents into soft copies to later be transmitted from one place to the other via the internet. This format can include colours, unlike the typical fax machine.

\section{Printers and Photocopiers}

Printers are used to convert our documents from soft copy formats to hard copies and photocopiers are used to make additional copies of such documents.

\section{ADVANTAGES OF OFFICE EQUIPMENT}

- Information that is the most important to the office can be stored, processed, and retrieved by computer facilities.

- $\quad$ They can be used to produce fast and accurate information.

- $\quad$ They provide very cheap services.

- $\quad$ Messages can be sent to many people simultaneously.

- $\quad$ Security of information is assured.

- $\quad$ Time, effort and money are saved.

- $\quad$ Stress is minimized.

- $\quad$ You can purchase office items online.

- You can book airline tickets and hotels online.

- $\quad$ Space is saved as little or no paper is used in the office.

\section{DISADVANTAGES OF OFFICE EQUIPMENT}

- $\quad$ They are expensive because not all people can afford them.

- $\quad$ They use electricity, without which they cannot be used.

- $\quad$ Messages sent via the internet can be insecure. 
- $\quad$ They have attracted vices; i.e., Internet fraud or cyber crime and robbery.

- $\quad$ Some of the machines require training, which scares some people.

- Some equipment, especially computers, is easily outdated as new inventions and discoveries make the present ones obsolete.

\section{THE THIRD MILLENNIUM SECRETARY AND HIS ENVIRONMENT}

The third millennium secretary is facing a lot of challenges and changes. He is, therefore, in a world of "survival of the fittest." The challenges and changes are in his academic qualifications, acquisition of skills, the environment, roles and responsibilities, office hazards, and nomenclature.

\section{Academic Qualifications}

Secretaries today go to tertiary institutions (polytechnics and universities). The curriculum of the secretarial course keeps changing to include internet application, word processing, desktop publishing, records management, time management, business law, accounting, information and communication technology, etc. For small organizations, secondary school graduates with basic skills may be employable.

\section{Acquisition of Skills}

The emphasis on shorthand is being reduced, but the emphasis on typing is maintained because of its usefulness on the computer keyboard. He must be versatile on many tasks. He must be adept on the computer in word processing, spreadsheets, CorelDraw, and desktop publishing. He must also acquire good communication skills and must possess human and public relations skills.

\section{Environment}

The office has moved from closed to open. Although we still have closed offices, we have more that are open. The open offices have more advantages than disadvantages, especially in terms of cost and supervision. Equipment is not duplicated, computers are now common devoid of manual typewriters, the office furniture is more comfortable, there is less paper usage, the office now has more space devoid of many filing cabinets, and most offices use air conditioners since fans are becoming outdated. Because of the air conditioner, most buildings are poorly ventilated.

\section{Roles and Responsibilities}

The secretary is an assistant to a manager. He plays supportive roles; however, the third millennium secretary's role has increased. Apart from the traditional responsibilities, such as typing, taking dictation and transcribing, managing records, receiving, storing and retrieving information or operating the computer, attending meetings, answering telephone calls, he now carries out research, prepares the manager's itinerary, makes travel bookings and hotel reservations, supervises the junior workers, and makes some decisions using his initiatives. He should be able to answer some questions on behalf of the boss. For example, a client who wants the price of a product should not wait to see the boss. A secretary who is familiar with the company's policies, price list and handbooks should relieve the boss of such burden by providing accurate information.

He should be able to coordinate the administrative activities and organize the office for efficient performance. He should be able to use the internet and train new staff on the computer. The secretary is a member of a team in the workplace and therefore should always be cooperative and supportive. He should be able to write and present reports and disseminate information using websites and e-mail. He now shares with the manager the responsibilities that were hitherto reserved for the manager. 


\section{Office Hazards}

The office today has changed, just as we have new innovations and invention in technology. It is common to hear many Nigerian companies, especially banks, talking about "re-engineering." During this period, the offices are reorganized and rearranged. Walls are broken, new technologies are introduced, new security devices are put in place, new furniture is brought in and the floors are replaced with tiles.

The most obvious office hazard is air pollution. Because of the use of air conditioners in offices, there is no adequate ventilation. Some people smoke and some have one disease or another. Makower (1982) quoted an Atlanta microbiologist who likened a secretary in an inadequate ventilated office to "just like everybody in the house taking a bath in the same bath water without changing it. That's what happens to the air when a lot of people share it and it doesn't get changed." The glare from fluorescent lights and uncomfortable chairs, as well as sitting for a long time (even on comfortable chairs) causes stress, headaches, backaches, high blood pressure, etc. Makower (1982) pointed out that there is radon 222, a radioactive gas emitted from concrete and brick that causes lung cancer.

Another hazard that the invention of new technology brought, especially the computer terminals, is eyestrain. Backache, neck pains, stomach aches, cataracts, stress and high blood pressure are all associated with the use of video display terminals (VDTs) used in offices. Noise from telephones and people's conversations can also cause workers' stress. We have seen people falling down on slippery floors, thus adding more to the environmental hazards.

\section{Nomenclature}

Because of the changes in roles and responsibilities of modern office secretaries, their titles have also changed. The secretary is now given many titles, such as office coordinator, executive assistant, office manager, administrative professional, Government secretary (Parliamentary Private Secretary, Secretary of State, etc.), Medical secretary, Legal secretary, Bi-lingual secretary, Technical secretary and Office professional, etc. The millennium secretaries are now specialized and their new titles show their areas of specialization.

\section{CONCLUSION}

Although Nigeria is a developing country, some people believe that it is a rich country because of its oil. Nigerians are very enthusiastic in accepting changes. However, with regard to the secretary and office technology, the secretaries are regularly retrained, but most of the offices do not have computers; and those who have, could not use them because of power outages. The tertiaries, who train the secretaries, do not have computers for the training and those who have computers cannot use them because electricity supply is not regular. Most secretaries pursue computer studies in privately established computer centres where generators are used for the computers to function. However, they pay for the use of generators through high course fees.

The secretary is very versatile and his profession is a very dynamic one. The traditional secretary has some personal and business attributes that are still relevant for the third millennium secretary. However, the third millennium secretary must be adaptable to ever-increasing changes in the workplace. There are changes in courses of study, in roles and responsibilities, innovations and inventions in technology, especially the varied uses of the computer. The structure of the office keeps changing. There are also hazards in the office that the secretary has to contend with. In fact, there are challenges that continue and only the secretary, who is hard working, will be able to survive in the work world. The indolent ones will certainly be pushed out of the workplace.

\section{RECOMMENDATIONS}

In order for the secretary to cope with the office environment and his dynamics, he should undergo regular re-training. Courses that should be included in the training package are: Change Management, Time Management, Resources Management, Records Management, Information and Communication Technology, Human and Public Relations, Accounting, Business Law, Desktop Management, Internet Application, Proofreading and Editing, etc. 


\section{AUTHOR BIOGRAPHY}

Dr Adewale Onifade is a Nigerian. He is married. He received his NCE in 1974 from National Technical Teachers College, Akoka, B.Sc in Business Education ( $2^{\text {nd }}$ class upper) in 1978 from the University of Nigeria, Nsukka. He received his master's degree and Ph.D. from Bowling Green State University, Ohio, in 1983 and 1985 respectively. He enjoyed scholarship awards for his post secondary education. He had taught at all levels of educational system. He was a teaching fellow at Bowling Green State University. He is a member of local and international professional associations. He has authored many textbooks and journal articles.

\section{REFERENCES}

1. Guralink, David B. (Ed). (1980). Webster NewWorld Dictionary. New York: Simon and Schuster.

2. Harrison, John. (1979). Secretarial Duties. London. Pitman Publishing Limited.

3. Kreitner, Robert. (1980). Management: A Problem Solving Process. Boston: Houghton Mifflin Company.

4. Lauria, Morrie. (1972). How to be a Good Secretary. New York: Harper and Row Publishers

5. Makower, Joel. (1982). “Office Hazards.” The Secretary. Washington DC: Tiden Press. Pp 12-14.

6. Nwankwo, John I (1985). Fundamentals of Management Information Systems. Ibadan: Spectrum Books ltd

7. $\quad$ Ogbenchie Chris (1991), "The Chief executive and the Executive Secretary." Journal of secretary and management. First Edition.

8. Onifade, Adewale. (2003). "Professionalism in academics" being a text of paper presented at the School of Business and Management Studies, MAPOLY, Abeokuta, Ogun State, Nigeria

9. Onifade, Adewale. (2004). Management: Office. Business Education. Revised Ed. Abeokuta: KAPPCO.

10. Pallister, John Isaacs, Alan. (Eds.). (2002). Oxford Dictionary of Business. Oxford: Oxford University press.

11. Sanders, Donald H. (1985). Computers Today. New York: Mc Graw Hill Book Company.

12. Wolf, Morris Philip \& Kuiper, Shirley. (1984). Effective Communication in Business.. Cincinnati: Southwest Publishing Co.

13. http://en.wikipedia.org/wiki/publicrelations

14. http://www.secretarialsite.com/secretarial-ethics.html 


\section{APPENDIX}

\section{HISTORY OF THE SECRETARIAL PROFESSION (Office Technology Time Line)}

$\underline{\text { Date }}$

1870 s

1880 s

1890 s

1900s

1910s

1920s

1930s

1940s

$1950 \mathrm{~s}$

1960s

1970s

1980s

1990s

2000 \& Beyond

\section{Inventions}

Telephone, typewriter, carbon paper

Comptometer calculating machine, mimeograph machine, cash register, adding machine, pneumatic tubes

Dictating and stenographic machines

Loose-leaf ledger sheets, multigraph, two color typewriter ribbon, addressograph

Power statistical accounting machine, Bookkeeping and billing machines (combinations of typewriter and computing machines)

Adding/subtracting calculating machine, ditto machines (gelatin duplicating)

Bank check sorting/proofing machines, dial telephones, electric typewriters (earliest versions, machine accounting systems, central records control, payroll)

Mechanical listing printing calculations, punched card systems (payroll), Dictaphone/stenographic machines with plastic belts

Electronic digital computers (transistors), electronic digital computers (vacuum tubes), data processing (paper and tape cards), xerographic duplication, data processing (telewriters), data processing (computypers)

Magnetic tape "selectric" typewriters, microchip computers, magnetic tape (replacing punched cards), magnetic ink character recognition, electronic (solid state), calculating machines

Microcomputers, optical scanning and recognition equipment, video display terminals for data/text editing, facsimile transmission

Local area networks, integrated systems, non-impact printers, software packages for microcomputers

PCs, E-mail, Internet

Wireless networks, voice recognition, electronic document collaboration, virtual meetings, virtual assistants 